\title{
Effect of Dietary Curcumin on the Antioxidant Status of Laying Hens under High-Temperature Conditions
}

Original Article

\begin{tabular}{|c|c|}
\hline Nawab $A^{\prime *}$ & (iD) https://orcid.org/0000-0003-3420-7547 \\
\hline Li G"* & (D) https://orcid.org/0000-0003-2960-4820 \\
\hline Liu W' & (iD) https://orcid.org/0000-0002-6493-8044 \\
\hline Lan $\mathrm{R}^{\prime}$ & (iD) https://orcid.org/0000-0002-6934-4448 \\
\hline Wu J' & (iD) https://orcid.org/0000-0002-8148-0178 \\
\hline Zhao $Y^{\prime}$ & (iD) https://orcid.org/0000-0002-4056-1625 \\
\hline Kang $\mathrm{K}^{\prime}$ & (iD) https://orcid.org/0000-0001-9760-9864 \\
\hline Kieser B"II & (iD https://orcid.org/0000-0002-2732-705x \\
\hline Sun $\mathrm{C}^{\prime}$ & (iD) https://orcid.org/0000-0002-4144-6311 \\
\hline Tang S' & (iD https://orcid.org/0000-0002-5459-8605 \\
\hline Xiao $M^{\prime}$ & (iD) https://orcid.org/0000-0002-5867-7044 \\
\hline An L' & (iD) https://orcid.org/0000-0002-1371-7946 \\
\hline
\end{tabular}

Department of Veterinary Medicine, Agricultural College, Guangdong Ocean University, Zhanjiang 524088, Guangdong, China.

Department of Animal Science, Agricultural College, Guangdong Ocean University, Zhanjiang 524088, Guangdong, China.

III Department of Foreign Language, Guangdong Ocean University, Zhanjiang 524088, Guangdong, China.

*These two authors (Aamir Nawab and Guanghui Li) contributed equally to this paper

\section{-Mail Address}

Corresponding author e-mail address Lilong An

Department of Livestock Productions and Management, Agricultural College,

Guangdong Ocean University, Haida Road, Mazhang District, Zhanjiang 524088,

Guangdong, China.

Email: anlilong@126.com

\section{-Keywords}

Antioxidant; curcumin; heat stress; laying hen; oxidative damage.

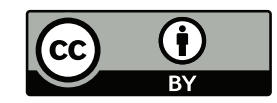

Submitted: 26/October/2018 Approved: 04/February/2019

\section{ABSTRACT}

Heat stress induces oxidative stress, and reduces body antioxidant metabolite levels, which can affect poultry production performance. Dietary antioxidants protect birds against the adverse effects of heat stress. The effects of increasing concentrations of dietary curcumin on the antioxidant parameters of layers maintained under high-temperature conditions for nine weeks were evaluated. Roman laying hens $(n=336$, 22 weeks old, $1420 \mathrm{~g} \mathrm{BW}$ ) were divided into three treatment groups. The first group served as a thermoneutral control (kept at $25 \pm 1{ }^{\circ} \mathrm{C}$ ). The second group was exposed to high temperatures $\left(32 \pm 1{ }^{\circ} \mathrm{C}, 6\right.$ $\mathrm{h} / \mathrm{d}$ ), given a basal diet. The third group was further divided into five treatment groups (100, 150, 200, 250, $300 \mathrm{mg} / \mathrm{kg}$ Curcumin) fed a basal diet (treatments $\mathrm{H} 1, \mathrm{H} 2, \mathrm{H} 3, \mathrm{H} 4, \mathrm{H} 5$ ) under high temperatures conditions ( $32 \pm 1{ }^{\circ} \mathrm{C}, 6$ hours/day). As a result of this study, total superoxide dismutase activity was significantly higher in $\mathrm{H} 2$ and $\mathrm{H} 3$ groups, and total antioxidant capacity was higher in $\mathrm{H} 2, \mathrm{H} 3$, and $\mathrm{H} 5$ groups. Catalase and glutathione peroxidase activity was significantly higher in the $\mathrm{H} 3$ group. Malondialdehyde concentration was lowered in curcumin supplemented hens compared with control groups hens. Laying hens in all curcumin treatment groups had slightly higher activities of CAT, SOD, GSH-Px, and T-AOC in the liver, heart, and lungs, compared with heat stressed control group. It was concluded that dietary curcumin given to laying hens under heat stress may enhance their antioxidant status, and alleviate the detrimental effects of stressful environmental conditions.

\section{INTRODUCTION}

In hot climatic regions of the world, heat stress (HS) causes oxidative stress in poultry (Lin et al., 2006; Habibi et al., 2014). Oxidative stress causes tissue damage and impair disease resistance, resulting in performance losses (Dhanalakshmi et al., 2007; Rahmani et al., 2017; Nawab et al., 2018). In southern China, in particular, high environmental temperatures disturbs poultry thermoregulation due to long duration of summer. Thermogenic mechanisms depend on fast metabolism in birds (Guo et al., 2007). However, fast metabolism rates increase the oxygen demand in the body tissues (Rahmani et al., 2017). Stressful conditions create an imbalance between oxygen demand and supply, thereby resulting in hypoxemia (Hassanzadeh et al., 2014). Hypoxia increases the production of free radicals (Reis et al., 2013), which in turn increases the activities of circulating enzymes, disturbing normal body functions (Arab et al., 2006; Rahmani et al., 2017).

Antioxidants protect cells from the effects of lipid peroxidation. Lipid peroxidation is an indicator of cellular injury due to generation of free radicals (Dinkova-Kostova \& Talalay 2008; Wu et al., 2016). Several 
synthetic antioxidants have been banned due to their liver-carcinogenicity properties (Rahmani et al., 2017). On the other hand, several studies have reported that plant substances included in animal feeds provide the beneficial effects, including antioxidant action, activation of immune responses, as well as stimulation of appetite and improvement of endogenous digestive enzyme secretion (Ledoux, 2009; Toghyani et al., 2011; Nawab et al., 2018). Recently, curcumin, a yellow pigment of turmeric, has been considered a potential natural antioxidant feed additives (Wang et al., 2015; Ramos et al., 2017). Turmeric (Curcuma longa L) belongs to ginger family and is found in the southern and southeastern Asia (Nouzarian et al., 2011).

Curcumin is the main compound present in of turmericplant (Nouzarian et al., 2011; Wang et al., 2015; Arslan et al., 2017), and has been shown to have a wide range of therapeutic and pharmacological properties, including antioxidant, anti-inflammatory, free-radical scavenging, lipid peroxidation inhibition, antimicrobial, antiviral, antiprotozoal, and antitumor activities. In addition, turmeric may act boost the immune response (Cleary \& McFeeters, 2006; Singh et al., 2010; Zhang et al., 2014; Wang et al., 2015; Pulido-Moran et al., 2016; Amalraj et al., 2017). Those curcumin biological properties make it a potential antioxidant feed additive for poultry. Therefore, the aim of our research was to evaluate the effects of increasing levels of dietary curcumin on antioxidant status of laying hens maintained under high environmental temperature conditions to determine if the harmful effects of heat stress could be alleviated.

\section{MATERIALS AND METHODS}

\section{Birds, housing, experimental design, and diets}

A total of 336 day-old Roman layers were purchased from Guangzhou poultry industry in Guangzhou, China. Birds were transported to the Department of Animal Sciences, Agricultural College, Guangdong Ocean University, where they were housed in battery cages (2 hens/cage), equipped with hopper feeder and nipple or cup drinker. Hens were provided with water and feed ad libitum throughout the experimental period.

Hens were evaluated from 22 (1420 g body weight) to 31 weeks of age (1940 g body weight). Hens were kept in an environmentally-controlled room (with controlled temperature, humidity, and light conditions until 22 weeks of age. In week 22, hens were divided into the following treatment groups: thermoneutral control group ( $T C ; n=84)$, heat stress control group $(H C ; n=84)$ and heat stress treatment groups $(H T ; n=84)$ named as $\mathrm{H} 1, \mathrm{H} 2, \mathrm{H} 3, \mathrm{H} 4, \mathrm{H} 5$. The thermoneutral environment was characterized by comfort temperatures of $25 \pm 1$ ${ }^{\circ} \mathrm{C}$ and $45-55 \%$ relative air humidity (RH). Heat stress was characterized by submitting birds to $32 \pm 1{ }^{\circ} \mathrm{C}$ for 6 hours/day, between 10:00 and 16:00 h and 55$65 \% \mathrm{RH}$ for nine weeks. Hens in the TC group were fed a basal diet formulated to supply layer nutritional requirements according to the NRC, (1994) (Table 2). The hens in the heat stress control group were fed the same basal diet as the TC hens, with no curcumin addition, and heat stress treatment group were given basal diet supplemented with curcumin at 100,

Table 2 - Ingredients and chemical composition of the experimental basal diet.

\begin{tabular}{lccc}
\hline Ingredients & Percent (\%) & Nutrients (Analyzed composition, \%) & Content \\
\hline Corn CP 8\% & 62.8 & ME /(MJ/kg) & 11.42 \\
Soybean meal CP 44\% & 20.0 & CP, \% & 18.17 \\
Wheat bran 12\% & 2.0 & Ca, \% & 3.7 \\
Fish meal CP 62\% & 4.5 & TP, \% & 0.58 \\
Limestone, \% & 9.0 & Met, \% & 0.41 \\
CaHPO 4\% & 1.0 & Cys, \% & 0.29 \\
NaCl, \% & 0.2 & Lys, \% & 0.94 \\
Premix & 0.5 & & \\
\hline
\end{tabular}

Notes: 'The premix provided, per kg of diet: Vitamin A 9000 IU; Vitamin D 2500 IU; Vitamin E 20 IU; Vitamin B $1212 \mu$; Vitamin K 2.4 mg; Mn100 mg; Zn 60 mg; Fe 25 mg, Cu 5 mg; Co $0.1 \mathrm{mg}$ (Mn, Zn, Fe, Cu, Co were provided in the form of sulfates); Se (N2SeO3.5H2O) 0.2 mg; I(KI) 0.5mg.

${ }^{1}$ Calculated values were according to NRC (1994) values for feedstuffs.

$150,200,250,300 \mathrm{mg} / \mathrm{kg}$ of feed, corresponding to treatments $\mathrm{H} 1, \mathrm{H} 2, \mathrm{H} 3, \mathrm{H} 4, \mathrm{H} 5$, respectively. The experimental treatments are described in Table 1.

Dietary curcumin was obtained from Agricultural Vegetable Limited Company in Xi'an, China. Curcumin was composed of $77 \%$ curcumin, $18 \%$ dimethoxy curcumin, and $5 \%$ bisdemethoxy curcumin (Rahmani et al., 2017). The purity of the curcumin used in this study was $95 \%$. Curcumin was first added to a small amount of basal diet and then thoroughly mixed with $100 \mathrm{~kg}$ feed at the required amounts to obtain the HS1, HS2, HS3, HS4, and HS5 diets. 
Nawab A, Li G, Liu W, Lan R, Wu J, Zhao Y, Kang K, Kieser B, Sun C, Tang S, Xiao M, An L
Effect of Dietary Curcumin on the Antioxidant Status of Laying Hens under High-Temperature Conditions
Table 1 - Diets fed to laying hens in this study.

\begin{tabular}{lcl}
\hline Treatments & Abbreviations & \multicolumn{1}{c}{ Diet } \\
\hline Thermo-neutral control & TC & Basal diet \\
Heat control & HC & Basal diet \\
Treatment 1 & H1 & Basal diet $+100 \mathrm{mg} / \mathrm{kg}$ curcumin \\
\hline Treatment 2 & H2 & Basal diet $+150 \mathrm{mg} / \mathrm{kg}$ curcumin \\
Treatment 3 & H3 & Basal diet $+200 \mathrm{mg} / \mathrm{kg}$ curcumin \\
Treatment 4 & H4 & Basal diet $+250 \mathrm{mg} / \mathrm{kg}$ curcumin \\
Treatment 5 & H5 & Basal diet $+300 \mathrm{mg} / \mathrm{kg}$ curcumin \\
\hline
\end{tabular}

\section{Blood sampling and determination of antioxidant enzyme activities}

Blood samples were taken from the wing vein of three randomly-selected hens fasted overnight per replicate during the $3^{\text {rd }}, 6^{\text {th }}$ and $9^{\text {th }}$ week of the experiment. Each sample was collected in two tubes (one with and one without EDTA as an anticoagulant). Blood samples were kept at room temperature for 45 min, and the serum was obtained by centrifugation at $700 \mathrm{~g}$ for $10 \mathrm{~min}$. Serum was stored in $2 \mathrm{~mL}$ plastic vials at $-20{ }^{\circ} \mathrm{C}$ for further analysis.

Liver, lung, and heart tissue samples were also collected for measurement of antioxidant enzymatic activities, and stored at $-20^{\circ} \mathrm{C}$. The tissue samples were prepared in PBS (phosphate buffered saline) buffer, and centrifuged at 2,500 $\mathrm{g}$ for $10 \mathrm{~min}$ at $4{ }^{\circ} \mathrm{C}$. The assays were conducted according to the procedures described by Wang et al. (2015). Serum catalase (CAT) activity was assessed by the method described by Sippy et al. (2003) (ELISA kit: QuantiChrom, BioAssay Systems, USA, Catalog No. ECAT-100). Superoxide dismutase (SOD) activity was measured using the xanthine and xanthine oxidase method (ELISA kit: Cayman Chemical Company, USA, Catalog No. 706002), which measures the inhibition of the nitroblue tetrazolium reduction reaction in extracts of the collected tissue samples(Sun et al. 1988). Serum glutathione peroxidase (Gpx) was measured using $\mathrm{H}_{2} \mathrm{O}_{2}$ and a specific dye containing an electron donor that results in a pink color during the peroxide reaction (ELISA Kit: QuantiChrom, Bioassay Systems, USA, Catalog No. DPOD-100), following Kokkinakis \& Brooks (1979). Serum total antioxidant capacity (TAC) was measured by using a Randox total antioxidant status kit (Randox Laboratories Ltd, Crumlin, UK). Serum malondialdehyde (MDA) levels, as an indicator of lipid peroxidation, were determined by using thiobarbituric acid reactive substances (TBARS) produced during oxidative stress (Ohkawa et al. 1979) (ELISA Kit: QuantiChromTM, Bioassay Systems, USA, Catalog No. DTBA-100), according to Ohkawa et al. (1979). The assays were conducted according to the manufacturers' protocols.

\section{Statistical analysis}

Statistical analysis was carried out using (SPSS Statistical Software, 1968). Data were submitted to one-way analysis of variance, and means compared by Duncan' significant difference test (Steel et al., 1997). All data are expressed as means \pm standard error (SEM). Results were considered statistically significant at $p<0.05$.

\section{RESULTS AND DISCUSSION}

Several stress factors cause the generation of reactive oxygen species (ROS), such as superoxide $\left(\mathrm{O}_{2}\right)$ and hydrogen peroxide $\left(\mathrm{H}_{2} \mathrm{O}_{2}\right)$, which lead to oxidative stress (Zeng et al., 2014). Oxidative stress can be described as an imbalance between pro-oxidant and antioxidant metabolites (Daneshyar, 2012; Ismail et al., 2013). Elevated levels of ROS can overwhelm cellular homeostasis by initiating lipid peroxidation, oxidation of proteins, and inhibition of enzymes, that ultimately lead to cell death (figure 1)(Maheshwari \& Dubey, 2009; Srivastava \& Dubey, 2011; Zeng et al., 2014). Antioxidant metabolites (SOD, CAT, T-AOC, and GSH-Px) play the role of defense mediators in animal bodies (Daneshyar, 2012). Decreased or increased concentrations of antioxidant metabolites and free radicles (ROS) have detrimental effects on body tissues, which in turn, result in the manifestation of diseases (Wang et al., 2015). MDA is one of main products of lipid peroxidation, and can be monitored by determining MDA concentrations in serum and tissue samples (Wang et al., 2015).

Curcumin was shown to present excellent antioxidant and anti-inflammatory activities (Yarru et al., 2009; Nouzarian et al., 2011; Rahmani et al., 2017). Curcumin is a main antioxidant element of turmeric plants (Cousins et al., 2007; Wang et al., 2015). It has

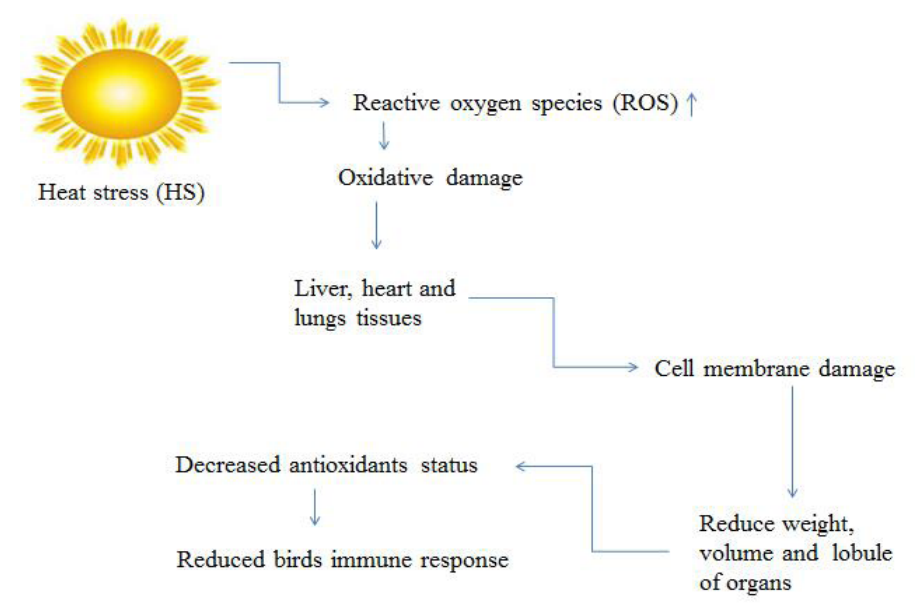

Figure 1 - Effect of heat stress on poultry health. 
the specific ability to scavenge free radicals (including superoxide anions and hydroxyl radicals) and hinder lipid peroxidation (Yarru et al., 2009; Wang et al., 2015).

Studies have reported that curcumin given to rats had inhibited lipid peroxidation in liver microsomes and erythrocyte membranes (Chattopadhyay et al., 2004; Wang et al., 2015). In our experiment, positive effects of curcumin on the antioxidant and oxidant status of serum and tissues samples of laying hens submitted to heat stress for nine weeks were detected (Figure 2). Serum SOD activity was significantly $(p<0.05)$ higher in hens maintained in TC compared with HS hens fed no curcumin in all evaluated weeks. SOD activity was significantly $(p<0.05)$ increased in heat-stressed groups fed curcumin at 150 and $200 \mathrm{mg} / \mathrm{kg}$ (HT150 and HT200) in the $3^{\text {rd }}$ and $9^{\text {th }}$ week of the experiment, respectively, compared with the TC and HC group, which were fed only the basal diet. In the $6^{\text {th }}$ week of the experiment, heat-stressed hens supplemented with all curcumin levels (HT100, HT150, HT200, HT250, HT300 mg/kg) had increased serum SOD activity, but results were not statistically significant ( $p>0.05)$. These results were in accordance with Daneshyar (2012).

Table 3 presents antioxidant metabolite activities determined in the serum of the experimental hens. Serum T-AOC activity was significantly $(p<0.05)$ higher in curcumin-fed hens in a dose-dependent manner compared with the heat stressed control group (not supplemented with curcumin) during weeks 3, 6,

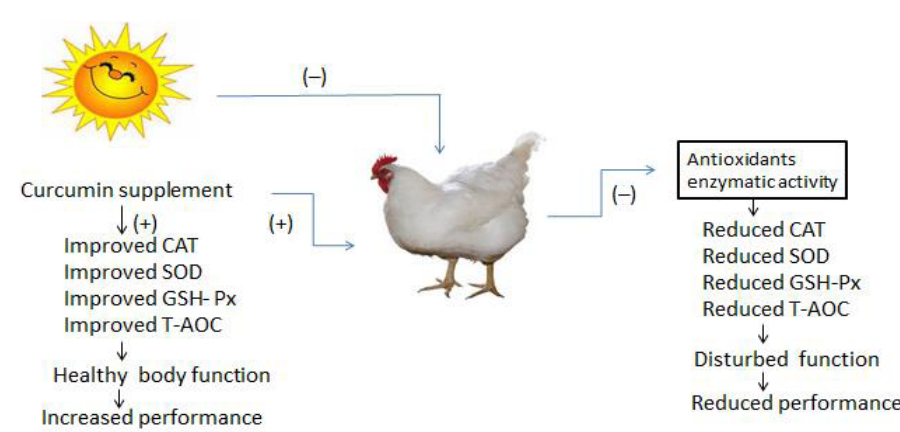

Figure 2 - Effect of dietary curcumin on poultry performance.

CAT; Catalase, SOD; Superoxide dismutase, GSH-Px; glutathione peroxidase, T-AOC; Total antioxidant capacity.

and 9 of the experiment, as previously discussed by Daneshyar (2012). Serum T-AOC activity was significantly $(p<0.05)$ enhanced in groups HT200, HT150, and HT250 during the $3^{\text {rd }}, 6^{\text {th }}$, and $9^{\text {th }}$ week of the experiment, respectively, compared with the HC group, fed only the basal diet. Serum CAT activity was significantly $(p<0.05)$ increased in the serum samples of hens in heat-stressed curcumin supplemented groups HT150 and HT200 during week 3 and HT200 during week 9 of the experiment when compared with the heat stress $(\mathrm{HC})$ control group, which is in accordance with Wang et al. (2015). On the other hand, in 6 week of the experiment, heat stress curcumin supplemented groups (HT100, HT150, HT200, HT250 and HT300 mg/ $\mathrm{kg}$ ) showed significantly $(p<0.05)$ higher serum CAT activity compared with the $\mathrm{HC}$ group, given only the basal diet.

Table 3 - Serum antioxidant metabolites of control hens (TC; no heat stress, no curcumin), heat stressed hens not supplemented with dietary curcumin $(\mathrm{HC})$ and heat stressed hens supplemented with different concentrations of dietary curcumin ( $\mathrm{H} 1, \mathrm{H} 2, \mathrm{H} 3, \mathrm{H} 4, \mathrm{H} 5$, for concentrations see Table 1) for nine weeks. Data are shown as mean \pm SEM.

\begin{tabular}{|c|c|c|c|c|c|c|c|c|}
\hline Parameters ${ }^{1}$ & $\begin{array}{c}\text { Time } \\
\text { (Week) }\end{array}$ & $\mathrm{TC}$ & $\mathrm{HC}$ & $\mathrm{H} 1$ & $\mathrm{H} 2$ & H3 & $\mathrm{H} 4$ & $\mathrm{H} 5$ \\
\hline \multirow{3}{*}{$\mathrm{SOD}(\mathrm{U} / \mathrm{mL})$} & 3 & $43.8 \pm 2.83^{\mathrm{a}}$ & $40.60 \pm 3.32^{b}$ & $42.36 \pm 3.00^{\mathrm{ab}}$ & $43.44 \pm 2.81^{\mathrm{a}}$ & $41.12 \pm 2.56^{\mathrm{ab}}$ & $40.70 \pm 2.59^{b}$ & $43.03 \pm 2.55^{\mathrm{ab}}$ \\
\hline & 6 & $43.2 \pm 3.25^{\mathrm{a}}$ & $35.31 \pm 5.76^{b}$ & $39.01 \pm 4.00^{\mathrm{ab}}$ & $41.84 \pm 4.13^{\mathrm{ab}}$ & $41.78 \pm 2.16^{\mathrm{ab}}$ & $38.06 \pm 4.63^{\mathrm{ab}}$ & $38.40 \pm 4.26^{\mathrm{ab}}$ \\
\hline & 9 & $60.8 \pm 4.95^{\mathrm{a}}$ & $51.11 \pm 3.56^{b}$ & $61.31 \pm 5.38^{a}$ & $63.91 \pm 3.30^{a}$ & $63.32 \pm 5.07^{a}$ & $58.31 \pm 5.47^{\mathrm{ab}}$ & $57.47 \pm 4.05^{\mathrm{ab}}$ \\
\hline \multirow{3}{*}{ CAT (U/mL) } & 3 & $7.03 \pm 0.23^{\mathrm{ab}}$ & $5.30 \pm 0.50^{b}$ & $7.76 \pm 0.29^{a b}$ & $10.01 \pm 0.56^{a}$ & $8.79 \pm 0.40^{a}$ & $7.67 \pm 0.67^{\mathrm{ab}}$ & $5.97 \pm 0.34^{\mathrm{ab}}$ \\
\hline & 6 & $7.57 \pm 0.42^{b}$ & $4.81 \pm 0.66^{a}$ & $6.93 \pm 0.31^{b}$ & $6.52 \pm 0.27^{b}$ & $6.76 \pm 0.37^{b}$ & $6.24 \pm 0.39^{b}$ & $6.21 \pm 0.37^{b}$ \\
\hline & 9 & $10.1 \pm 0.82^{a b}$ & $6.30 \pm 0.36^{c}$ & $8.48 \pm 0.71^{b}$ & $9.96 \pm 0.78^{a b}$ & $12.43 \pm 3.42^{\mathrm{a}}$ & $9.87 \pm 0.73^{\mathrm{ab}}$ & $9.37 \pm 0.95^{b}$ \\
\hline \multirow{3}{*}{ T-AOC (U/mL) } & 3 & $10.5 \pm 4.17^{a}$ & $5.59 \pm 2.50^{b}$ & $6.16 \pm 4.43^{b}$ & $9.57 \pm 2.49^{\mathrm{ab}}$ & $5.94 \pm 2.74^{b}$ & $6.25 \pm 1.04^{b}$ & $9.06 \pm 1.78^{\mathrm{ab}}$ \\
\hline & 6 & $4.89 \pm 1.53$ & $3.00 \pm 1.23$ & $4.77 \pm 2.96$ & $4.93 \pm 1.66$ & $4.32 \pm 1.83$ & $4.23 \pm 2.31$ & $4.23 \pm 1.63$ \\
\hline & 9 & $4.54 \pm 1.87$ & $2.07 \pm 1.43$ & $4.36 \pm 1.68$ & $3.42 \pm 0.82$ & $3.55 \pm 2.22$ & $5.15 \pm 2.87$ & $4.08 \pm 1.29$ \\
\hline \multirow{3}{*}{ GSH-Px (U/mol) } & 3 & $262.2 \pm 34.81^{\mathrm{ab}}$ & $233.29 \pm 12.56^{c}$ & $239.58 \pm 19.11^{c}$ & $240.92 \pm 12.14^{c}$ & $287.71 \pm 33.26^{a}$ & $275.52 \pm 16.15^{a}$ & $248.98 \pm 18.45^{b c}$ \\
\hline & 6 & $324.2 \pm 12.39^{a}$ & $297.7 \pm 88.11^{\mathrm{a}}$ & $313.7 \pm 89.66^{a}$ & $288.5 \pm 76.83^{a}$ & $551.0 \pm 148.25^{b}$ & $328.5 \pm 48.96^{a}$ & $288.5 \pm 59.99^{a}$ \\
\hline & 9 & $321.22 \pm 12.39^{a b}$ & $277.66 \pm 48.15^{a}$ & $283.25 \pm 87.23^{\mathrm{ab}}$ & $278.20 \pm 46.43^{a}$ & $451.50 \pm 98.33^{b}$ & $329.50 \pm 78.66^{\mathrm{ab}}$ & $278.50 \pm 59.99^{a}$ \\
\hline \multirow{3}{*}{$\mathrm{MDA}(\mathrm{nmol} / \mathrm{mL})$} & 3 & $15.6 \pm 5.53^{b}$ & $18.58 \pm 4.24^{\mathrm{a}}$ & $17.38 \pm 4.15^{\mathrm{ab}}$ & $17.75 \pm 5.17^{\mathrm{ab}}$ & $17.42 \pm 7.66^{\mathrm{ab}}$ & $16.84 \pm 7.73^{\mathrm{ab}}$ & $16.38 \pm 4.52^{\mathrm{ab}}$ \\
\hline & 6 & $13.00 \pm 1.33^{b}$ & $15.77 \pm 0.19^{a}$ & $13.56 \pm 1.83^{\mathrm{ab}}$ & $13.99 \pm 0.58^{\mathrm{ab}}$ & $13.67 \pm 1.15^{\mathrm{ab}}$ & $13.11 \pm 1.35^{\mathrm{ab}}$ & $13.67 \pm 1.15^{\mathrm{ab}}$ \\
\hline & 9 & $14.0 \pm 1.53^{b}$ & $16.22 \pm 1.07^{\mathrm{a}}$ & $15.00 \pm 0.88^{\mathrm{ab}}$ & $15.67 \pm 0.58^{\mathrm{ab}}$ & $15.78 \pm 1.02^{\mathrm{ab}}$ & $14.83 \pm 0.88^{\mathrm{ab}}$ & $15.67 \pm 1.15^{\mathrm{ab}}$ \\
\hline
\end{tabular}

Note: Numbers with different lowercase letters are significantly different from each other $(p<0.05)$. Numbers not followed by different lowercase letters are not significantly different from each other $(p>0.05)$.

${ }^{1} \mathrm{SOD}=$ superoxide dismutase; CAT = catalase; T-AOC = total antioxidant capacity; GSH-Px = glutathione peroxidase; MDA = malondialdehyde. 


\section{Effect of Dietary Curcumin on the Antioxidant Status of Laying Hens under High-Temperature Conditions}

Furthermore, GSH-Px activity was also significantly $(p<0.05)$ higher in the serum samples of curcumin-fed HT200 group in the $3^{\text {rd }}$ and $6^{\text {th }}$ weeks of the experiment, whereas in the $9^{\text {th }}$ week, curcumin supplementation at 200 and $250 \mathrm{mg} / \mathrm{kg}$ (groups HT200 and HT250) increased GSH-Px activity compared with the nonsupplemented HC and TC groups. In addition, despite not statistically different ( $p>0.05)$, serum MDA levels were lower in all heat-stress groups fed the diets supplemented with curcumin in weeks 3, 6, and 9 of the experiment compared with the heat-stressed group fed the basal diet. Similar findings were reported by Cousins et al. (2007) and Daneshyar (2012).
Wang et al. (2015) indicated that dietary curcumin counteracts the process of lipid peroxidation and reduces the production of reactive free radicals which, in response, increase the concentrations of antioxidant metabolites in the poultry body. In the present experiment, hens in all curcumin-supplemented groups $(\mathrm{H} 1, \mathrm{H} 2, \mathrm{H} 3, \mathrm{H} 4, \mathrm{H} 5)$ had slightly higher activities of CAT, SOD, GSH-Px, and T-AOC in the liver, heart, and lung tissues compared with the-heat stressed control group (Wang et al., 2015).

Table 4 shows the results of antioxidant metabolites determined in the liver of the experimental birds. SOD activity was significantly $(p<0.05)$ increased in the $3^{\text {rd }}$

Table 4 - Assay of antioxidant metabolites in liver tissue of control hens (TC; no heat stress, no curcumin), heat stressed hens not supplemented with dietary curcumin $(\mathrm{HC})$ and heat stressed hens supplemented with different concentrations of dietary curcumin $(\mathrm{H} 1, \mathrm{H} 2, \mathrm{H} 3, \mathrm{H} 4, \mathrm{H} 5$, for concentrations see Table 1) for nine weeks.

\begin{tabular}{|c|c|c|c|c|c|c|c|c|}
\hline Parameters ${ }^{1}$ & $\begin{array}{l}\text { Time } \\
\text { (Week) }\end{array}$ & TC & $\mathrm{HC}$ & H1 & $\mathrm{H} 2$ & H3 & $\mathrm{H} 4$ & H5 \\
\hline \multirow{3}{*}{$\begin{array}{l}\mathrm{SOD} \\
(\mathrm{U} / \mathrm{mL})\end{array}$} & 3 & $143.88 \pm 22.83$ & $140.60 \pm 32.32$ & $142.36 \pm 32.00$ & $143.44 \pm 22.81$ & $141.12 \pm 22.56$ & $140.70 \pm 22.59$ & $143.03 \pm 23.55$ \\
\hline & 6 & $143.20 \pm 33.25$ & $135.31 \pm 53.76$ & $139.01 \pm 43.00$ & $141.84 \pm 43.13$ & $141.78 \pm 23.16$ & $138.06 \pm 42.63$ & $138.40 \pm 42.26$ \\
\hline & 9 & $160.81 \pm 42.95$ & $151.11 \pm 33.56$ & $151.31 \pm 25.38$ & $153.91 \pm 33.30$ & $153.32 \pm 53.07$ & $158.31 \pm 53.47$ & $157.47 \pm 42.05$ \\
\hline \multirow{3}{*}{$\begin{array}{l}\text { CAT } \\
(\mathrm{U} / \mathrm{mL})\end{array}$} & 3 & $19.32 \pm 1.51^{a}$ & $10.64 \pm 5.74^{b}$ & $13.66 \pm 6.53^{\mathrm{ab}}$ & $14.75 \pm 1.32^{\mathrm{ab}}$ & $16.74 \pm 0.99^{a b}$ & $19.02 \pm 0.52^{\mathrm{a}}$ & $11.49 \pm 0.87^{b}$ \\
\hline & 6 & $26.66 \pm 0.17^{a}$ & $15.41 \pm 4.20^{b c}$ & $20.18 \pm 3.76^{b}$ & $18.29 \pm 3.38^{b}$ & $18.88 \pm 5.94^{b}$ & $20.64 \pm 2.40^{b}$ & $14.21 \pm 0.98^{c}$ \\
\hline & 9 & $21.61 \pm 4.92$ & $18.20 \pm 5.36$ & $21.48 \pm 3.26$ & $18.84 \pm 4.85$ & $18.26 \pm 6.15$ & $22.17 \pm 5.77$ & $20.30 \pm 4.45$ \\
\hline \multirow{3}{*}{ T-AOC (U/mL) } & 3 & $8.54 \pm 1.17$ & $7.01 \pm 1.50$ & $7.16 \pm 1.43$ & $7.57 \pm 1.9$ & $6.65 \pm 1.74$ & $7.25 \pm 2.04$ & $7.56 \pm 1.23$ \\
\hline & 6 & $7.29 \pm 1.53^{\mathrm{a}}$ & $4.25 \pm 1.33^{b}$ & $5.77 \pm 2.56^{\mathrm{ab}}$ & $5.55 \pm 1.36^{\mathrm{ab}}$ & $6.32 \pm 1.83^{\mathrm{ab}}$ & $5.53 \pm 1.31^{\mathrm{ab}}$ & $4.26 \pm 1.63^{b}$ \\
\hline & 9 & $6.67 \pm 1.7$ & $5.58 \pm 1.43$ & $5.70 \pm 0.68$ & $6.02 \pm 0.2$ & $7.55 \pm 3.2$ & $5.85 \pm 2.87$ & $5.08 \pm 1.9$ \\
\hline \multirow{3}{*}{$\begin{array}{l}\text { GSH-Px } \\
(\mathrm{U} / \mathrm{mol})\end{array}$} & 3 & $162.29 \pm 34.81$ & $133.29 \pm 12.56$ & $139.58 \pm 19.11$ & $140.92 \pm 12.14$ & $187.71 \pm 43.26$ & $175.52 \pm 16.15$ & $158.98 \pm 18.45$ \\
\hline & 6 & $194.62 \pm 12.39$ & $197.75 \pm 88.11$ & $153.75 \pm 49.66$ & $188.50 \pm 76.83$ & $151.00 \pm 48.25$ & $228.50 \pm 48.96$ & $188.50 \pm 59.99$ \\
\hline & 9 & $191.22 \pm 12.39$ & $177.66 \pm 48.15^{a}$ & $183.25 \pm 67.23$ & $178.20 \pm 46.43$ & $151.50 \pm 58.33$ & $229.50 \pm 68.66^{a}$ & $178.50 \pm 59.99$ \\
\hline \multirow{3}{*}{$\begin{array}{l}\text { MDA } \\
(\mathrm{nmol} / \mathrm{mL})\end{array}$} & 3 & $3.67 \pm 0.53^{b}$ & $4.78 \pm 0.24^{\mathrm{a}}$ & $3.98 \pm 0.05^{\mathrm{ab}}$ & $3.75 \pm 5.17^{\mathrm{ab}}$ & $3.42 \pm 7.66^{\mathrm{ab}}$ & $4.04 \pm 1.73^{\mathrm{ab}}$ & $4.38 \pm 0.42^{\mathrm{ab}}$ \\
\hline & 6 & $4.00 \pm 1.33^{b}$ & $6.07 \pm 1.19^{a}$ & $4.90 \pm 1.33^{\mathrm{ab}}$ & $5.49 \pm 0.56^{\mathrm{ab}}$ & $4.67 \pm 2.11^{\mathrm{ab}}$ & $7.11 \pm 0.75^{a}$ & $5.67 \pm 1.45^{\mathrm{ab}}$ \\
\hline & 9 & $6.55 \pm 4.53^{b}$ & $8.22 \pm 2.07^{\mathrm{a}}$ & $8.01 \pm 2.88^{a}$ & $7.37 \pm 1.78^{\mathrm{ab}}$ & $7.78 \pm 1.08^{\mathrm{ab}}$ & $6.83 \pm 0.88^{\mathrm{ab}}$ & $9.67 \pm 1.45^{a}$ \\
\hline
\end{tabular}

Note: Numbers with different lowercase letters are significantly different from each other $(p<0.05)$. Numbers not followed by different lowercase letters are not significantly different from each other $(p>0.05)$.

${ }^{1} \mathrm{SOD}=$ superoxide dismutase; $\mathrm{CAT}=$ catalase; $\mathrm{T}-\mathrm{AOC}=$ total antioxidant capacity; GSH-Px = glutathione peroxidase; MDA = malondialdehyde.

week (treatments $\mathrm{H} 2$ and $\mathrm{H} 5), 6^{\text {th }}$ week (treatments $\mathrm{H} 2$ and $\mathrm{H3}$ ), and $9^{\text {th }}$ week (treatment $\mathrm{H} 4$ ) of the experiment compared with HC group fed only the basal diet. CAT activity was significantly $(p<0.05)$ increased in liver in the $3^{\text {rd }}$ week (treatment $\mathrm{H} 4$ ), $6^{\text {th }}$ week (treatment $\mathrm{H} 3$ and $\mathrm{H} 4$ ), and $9^{\text {th }}$ week (treatment $\mathrm{H} 4$ ) of the experiment compared with the $\mathrm{HC}$ group fed only the basal diet. T-AOC activity was also significantly $(p<0.05)$ increased in the $9^{\text {th }}$ week (treatment H3) of the experiment compared with the $\mathrm{HC}$ group fed only the basal diet; however, in the $3^{\text {rd }}$ and $6^{\text {th }}$ weeks of the experiment, the curcumin-supplemented diet fed to heat-stressed hens had no significant ( $p>0.05)$ effect on T-AOC activity. GSH-Px activity was also significantly $(p<0.05)$ increased in the liver of heat-stressed hens fed curcumin-supplemented diets in the $3^{\text {rd }}$ week (treatment H3), $6^{\text {th }}$ week (treatment H4), and $9^{\text {th }}$ week (treatment $\mathrm{H} 4$ ) of the experiment compared with the $\mathrm{HC}$ group fed only the basal diet.

Antioxidant metabolite activities assayed in the heart are shown in Table 5. SOD activity was significantly $(p<0.05)$ increased in heat-stressed hens fed curcuminsupplemented diets in the $6^{\text {th }}$ week (treatments $\mathrm{H} 2$ and $\mathrm{H} 3$ ) and $9^{\text {th }}$ week (treatments $\mathrm{H} 2$ and $\mathrm{H} 3$ ) compared with the $\mathrm{HC}$ group fed only the basal diet, but no statistical differences $(p>0.05)$ were detected in the $3^{\text {rd }}$ week. CAT activity was significantly $(p<0.05)$ increased in heat-stressed hens fed curcumin-supplemented diets in the $3^{\text {rd }}$ week (treatment $\mathrm{H} 3$ ), $6^{\text {th }}$ week (treatments $\mathrm{H} 1$ and $\mathrm{H} 5$ ), and $9^{\text {th }}$ week (treatment $\mathrm{H} 5$ ) of the experiment compared with the HC group fed only the basal diet. Heart T-AOC activity was also significantly $(p<0.05)$ 
Table 5 - Assay of antioxidant metabolites in heart tissues of control hens (TC; no heat stress, no curcumin), heat stressed hens not supplemented with dietary curcumin $(\mathrm{HC})$ and heat stressed hens supplemented with different concentrations of dietary curcumin $(\mathrm{H} 1, \mathrm{H} 2, \mathrm{H} 3, \mathrm{H} 4, \mathrm{H} 5$, for concentrations see Table 1) for nine weeks.

\begin{tabular}{|c|c|c|c|c|c|c|c|c|}
\hline Parameters $^{1}$ & $\begin{array}{l}\text { Times } \\
\text { (Week) }\end{array}$ & TC & $\mathrm{HC}$ & $\mathrm{H} 1$ & $\mathrm{H} 2$ & $\mathrm{H} 3$ & $\mathrm{H} 4$ & H5 \\
\hline \multirow{3}{*}{$\begin{array}{l}\text { SOD } \\
(\mathrm{U} / \mathrm{mL})\end{array}$} & 3 & $243.88 \pm 2.83$ & $240.60 \pm 3.32$ & $242.36 \pm 3.00$ & $243.44 \pm 2.81$ & $241.12 \pm 2.56$ & $240.70 \pm 2.59$ & $243.03 \pm 2.55$ \\
\hline & 6 & $243.20 \pm 3.25$ & $235.31 \pm 5.76^{b}$ & $239.01 \pm 4.00$ & $241.84 \pm 4.13$ & $241.78 \pm 2.16$ & $238.06 \pm 4.63$ & $238.40 \pm 4.26$ \\
\hline & 9 & $260.81 \pm 4.95$ & $251.11 \pm 3.56$ & $261.31 \pm 5.38$ & $263.91 \pm 3.30$ & $263.32 \pm 5.07$ & $258.31 \pm 5.47$ & $257.47 \pm 4.05$ \\
\hline \multirow{3}{*}{$\begin{array}{l}\text { CAT } \\
(\mathrm{U} / \mathrm{mL})\end{array}$} & 3 & $13.03 \pm 0.23^{a}$ & $4.00 \pm 1.04^{\mathrm{bc}}$ & $2.76 \pm 0.29^{c}$ & $6.01 \pm 0.56^{\mathrm{bc}}$ & $13.79 \pm 0.40^{\mathrm{a}}$ & $5.67 \pm 0.67^{\mathrm{bc}}$ & $7.97 \pm 0.34^{b}$ \\
\hline & 6 & $11.57 \pm 0.2$ & $9.81 \pm 0.66$ & $12.93 \pm 0.1$ & $10.52 \pm 0.7$ & $10.76 \pm 0.37$ & $11.24 \pm 0.39$ & $12.21 \pm 0.7$ \\
\hline & 9 & $9.99 \pm 0.82 \mathrm{ab}$ & $6.30 \pm 0.36 b$ & $8.88 \pm 0.71 \mathrm{ab}$ & $9.96 \pm 0.78 a b$ & $10.43 \pm 3.42 \mathrm{ab}$ & $8.87 \pm 0.73 a b$ & $12.37 \pm 0.95 \mathrm{a}$ \\
\hline \multirow{3}{*}{ T-AOC (U/mL) } & 3 & $4.54 \pm 4.1^{\mathrm{b}}$ & $3.59 \pm 2.5^{b}$ & $4.16 \pm 4.4^{b}$ & $5.57 \pm 2.4^{b}$ & $8.94 \pm 2.4^{a}$ & $9.25 \pm 1.4^{a}$ & $8.06 \pm 1.7^{\mathrm{a}}$ \\
\hline & 6 & $12.89 \pm 1.53^{\mathrm{a}}$ & $5.00 \pm 1.23^{b}$ & $12.77 \pm 2.96^{a}$ & $12.93 \pm 1.66^{a}$ & $12.32 \pm 1.83^{\mathrm{a}}$ & $9.23 \pm 2.31^{\mathrm{ab}}$ & $9.23 \pm 1.63^{\mathrm{ab}}$ \\
\hline & 9 & $3.54 \pm 1.87$ & $3.07 \pm 1.43$ & $3.36 \pm 1.68$ & $3.42 \pm 0.82$ & $3.55 \pm 2.22$ & $3.15 \pm 2.87$ & $3.08 \pm 1.29$ \\
\hline \multirow{3}{*}{$\begin{array}{l}\text { GSH-Px } \\
(\mathrm{U} / \mathrm{mol})\end{array}$} & 3 & $262.29 \pm 34.81^{\mathrm{ab}}$ & $233.29 \pm 12.56^{c}$ & $239.58 \pm 19.11^{c}$ & $240.92 \pm 12.14^{c}$ & $287.71 \pm 33.26^{a}$ & $275.52 \pm 16.15^{a}$ & $248.98 \pm 18.45^{b c}$ \\
\hline & 6 & $324.62 \pm 12.39^{a}$ & $297.75 \pm 88.11^{\mathrm{a}}$ & $313.75 \pm 89.66^{a}$ & $288.50 \pm 76.83^{a}$ & $551.00 \pm 148.25^{b}$ & $328.50 \pm 48.96^{a}$ & $288.50 \pm 59.99^{a}$ \\
\hline & 9 & $321.22 \pm 12.39^{\mathrm{ab}}$ & $277.66 \pm 48.15^{a}$ & $283.25 \pm 87.23^{\mathrm{ab}}$ & $278.20 \pm 46.43^{a}$ & $451.50 \pm 98.33^{b}$ & $329.50 \pm 78.66^{a b}$ & $278.50 \pm 59.99^{a}$ \\
\hline \multirow{3}{*}{$\begin{array}{l}\text { MDA } \\
\text { (nmol/mL) }\end{array}$} & 3 & $5.67 \pm 5.53^{b}$ & $10.58 \pm 4.24^{\mathrm{a}}$ & $7.38 \pm 4.15^{\mathrm{ab}}$ & $8.75 \pm 5.17^{\mathrm{ab}}$ & $8.42 \pm 7.66^{\mathrm{ab}}$ & $6.84 \pm 7.73^{\mathrm{ab}}$ & $9.38 \pm 4.52^{\mathrm{a}}$ \\
\hline & 6 & $5.00 \pm 1.3$ & $5.77 \pm 0.19$ & $5.56 \pm 1.3$ & $5.99 \pm 0.8$ & $5.67 \pm 1.5$ & $5.11 \pm 1.5$ & $5.67 \pm 1.5$ \\
\hline & 9 & $9.08 \pm 1.53$ & $10.22 \pm 1.07$ & $8.00 \pm 0.88$ & $8.67 \pm 0.58$ & $10.78 \pm 1.02$ & $14.83 \pm 0.88$ & $10.67 \pm 1.15$ \\
\hline
\end{tabular}

Note: Numbers with different lowercase letters are significantly different from each other $(p<0.05)$. Numbers not followed by different lowercase letters are not significantly different from each other $(p>0.05)$.

${ }^{1} \mathrm{SOD}=$ superoxide dismutase; $\mathrm{CAT}=$ catalase; $\mathrm{T}-\mathrm{AOC}=$ total antioxidant capacity; GSH-Px = glutathione peroxidase; MDA = malondialdehyde.

increased in the $3^{\text {rd }}$ week (treatments $\mathrm{H} 3$ and $\mathrm{H} 4$ ) and $6^{\text {th }}$ week (treatments $\mathrm{H} 1$ and $\mathrm{H} 2$ ) of the experiment compared with the HC group fed only the basal diet, but in the $9^{\text {th }}$ week, curcumin supplementation did not significantly $(p>0.05)$ affect T-AOC activity. Moreover, heart GSH-Px activity significantly $(p<0.05)$ increased in the $3^{\text {rd }}$ week (treatments $\mathrm{H} 3$ and $\mathrm{H} 4$ ), $6^{\text {th }}$ week (treatments $\mathrm{H} 3$ and $\mathrm{H} 5$ ), and $9^{\text {th }}$ week (treatment $\mathrm{H} 3$ ) of the experiment compared with the $\mathrm{HC}$ group given only basal diet.

Table 6 presents the activities of antioxidant metabolites determined in the lungs of the experimental layers. Lung SOD activity was significantly $(p<0.05)$ increased in the $3^{\text {rd }}$ week (treatment $\left.\mathrm{H} 2\right)$ and $9^{\text {th }}$ week (treatments $\mathrm{H} 2$ and $\mathrm{H} 3$ ) of the experiment in heat-stressed hens fed curcumin-supplemented

Table 6 - Assay of antioxidant metabolites in lung tissues of control hens (TC; no heat stress, no curcumin), heat stressed hens not supplemented with dietary curcumin $(\mathrm{HC})$ and heat stressed hens supplemented with different concentrations of dietary curcumin ( $\mathrm{H} 1, \mathrm{H} 2, \mathrm{H} 3, \mathrm{H} 4, \mathrm{H} 5$, for concentrations see Table 1) for nine weeks.

\begin{tabular}{|c|c|c|c|c|c|c|c|c|}
\hline Parameters ${ }^{1}$ & $\begin{array}{c}\text { Time } \\
\text { (Week) }\end{array}$ & $\mathrm{TC}$ & $\mathrm{HC}$ & $\mathrm{H} 1$ & $\mathrm{H} 2$ & $\mathrm{H} 3$ & $\mathrm{H} 4$ & H5 \\
\hline \multirow{3}{*}{$\begin{array}{l}\text { SOD } \\
(\mathrm{U} / \mathrm{mL})\end{array}$} & 3 & $86.24 \pm 2.32^{\mathrm{a}}$ & $80.20 \pm 3.32^{b}$ & $84.36 \pm 3.22^{\mathrm{ab}}$ & $86.44 \pm 2.22^{a}$ & $82.12 \pm 2.23^{\mathrm{ab}}$ & $80.70 \pm 2.32^{b}$ & $85.03 \pm 2.55^{\mathrm{ab}}$ \\
\hline & 6 & $88.20 \pm 3.25^{a}$ & $70.31 \pm 5.76^{b}$ & $78.01 \pm 4.00^{\mathrm{ab}}$ & $82.84 \pm 4.13^{\mathrm{ab}}$ & $82.78 \pm 2.16^{\mathrm{ab}}$ & $76.06 \pm 4.63^{\mathrm{ab}}$ & $76.40 \pm 4.26^{\mathrm{ab}}$ \\
\hline & 9 & $100.81 \pm 4.95^{\mathrm{a}}$ & $81.11 \pm 3.56^{b}$ & $91.31 \pm 5.38^{a}$ & $93.91 \pm 3.30^{a}$ & $93.32 \pm 5.07^{a}$ & $88.31 \pm 5.47^{\mathrm{ab}}$ & $87.47 \pm 4.05^{\mathrm{ab}}$ \\
\hline \multirow{3}{*}{$\begin{array}{l}\text { CAT } \\
(\mathrm{U} / \mathrm{mL})\end{array}$} & 3 & $18.03 \pm 0.23^{a}$ & $8.01 \pm 1.4^{c}$ & $7.74 \pm 1.20^{c}$ & $16.01 \pm 0.56^{\mathrm{ab}}$ & $12.79 \pm 0.40^{\text {bc }}$ & $16.67 \pm 0.67^{\mathrm{ab}}$ & $16.97 \pm 0.34^{\mathrm{ab}}$ \\
\hline & 6 & $21.57 \pm 0.42^{\mathrm{a}}$ & $4.85 \pm 2.6^{c}$ & $8.83 \pm 3.31^{c}$ & $22.52 \pm 0.27^{a}$ & $13.76 \pm 0.37^{b}$ & $19.24 \pm 0.39^{a}$ & $20.21 \pm 0.37^{a}$ \\
\hline & 9 & $19.19 \pm 0.82^{\mathrm{a}}$ & $8.30 \pm 0.36^{b}$ & $16.48 \pm 0.71^{\mathrm{ab}}$ & $29.96 \pm 0.78^{a}$ & $22.43 \pm 3.42^{\mathrm{a}}$ & $23.87 \pm 0.73^{a}$ & $16.37 \pm 0.95^{\mathrm{ab}}$ \\
\hline \multirow{3}{*}{ T-AOC (U/mL) } & 3 & $2.54 \pm 1.17$ & $1.59 \pm 0.50$ & $1.16 \pm 0.43$ & $2.57 \pm 2.49$ & $2.94 \pm 0.74$ & $1.25 \pm 1.04$ & $1.06 \pm 0.78$ \\
\hline & 6 & $1.89 \pm 1.53$ & $1.00 \pm 1.23$ & $1.77 \pm 2.96$ & $1.93 \pm 1.66$ & $1.32 \pm 1.83$ & $1.23 \pm 2.31$ & $1.23 \pm 1.63$ \\
\hline & 9 & $6.54 \pm 1.87^{\mathrm{ab}}$ & $4.07 \pm 1.43^{b}$ & $4.36 \pm 1.68^{b}$ & $5.42 \pm 0.82^{b}$ & $8.55 \pm 2.22^{\mathrm{a}}$ & $9.15 \pm 2.87^{\mathrm{a}}$ & $8.45 \pm 1.29^{a}$ \\
\hline \multirow{3}{*}{$\begin{array}{l}\text { GSH-Px } \\
(\mathrm{U} / \mathrm{mol})\end{array}$} & 3 & $242.29 \pm 34.81$ & $233.29 \pm 12.56$ & $239.58 \pm 19.11$ & $241.92 \pm 12.14$ & $247.71 \pm 33.26$ & $245.11 \pm 16.15$ & $248.98 \pm 18.45$ \\
\hline & 6 & $304.62 \pm 12.39$ & $297.75 \pm 88.11$ & $313.75 \pm 89.66$ & $208.50 \pm 76.83$ & $211.00 \pm 148.25$ & $218.50 \pm 48.96$ & $208.50 \pm 59.99$ \\
\hline & 9 & $321.22 \pm 12.39$ & $297.16 \pm 48.15$ & $303.15 \pm 87.13$ & $308.20 \pm 46.13$ & $311.50 \pm 92.33$ & $309.50 \pm 38.66$ & $298.50 \pm 49.99$ \\
\hline \multirow{3}{*}{$\begin{array}{l}\text { MDA } \\
(\mathrm{nmol} / \mathrm{mL})\end{array}$} & 3 & $6.67 \pm 5.53$ & $7.58 \pm 4.24$ & $7.38 \pm 4.15$ & $7.75 \pm 5.17$ & $6.42 \pm 7.66$ & $6.84 \pm 7.73$ & $6.38 \pm 4.52$ \\
\hline & 6 & $5.00 \pm 1.33$ & $4.77 \pm 0.19$ & $4.56 \pm 1.83$ & $4.99 \pm 0.58$ & $4.67 \pm 1.15$ & $4.11 \pm 1.35$ & $4.67 \pm 1.15$ \\
\hline & 9 & $5.08 \pm 1.53$ & $5.22 \pm 1.07$ & $5.00 \pm 0.88$ & $4.67 \pm 0.58$ & $4.78 \pm 1.02$ & $4.83 \pm 0.88$ & $5.67 \pm 1.15$ \\
\hline
\end{tabular}

Note: Numbers with different lowercase letters are significantly different from each other $(p<0.05)$. Numbers not followed by different lowercase letters are not significantly different from each other ( $p>0.05)$.

${ }^{\prime} \mathrm{SOD}=$ superoxide dismutase; $\mathrm{CAT}=$ catalase; $\mathrm{T}-\mathrm{AOC}=$ total antioxidant capacity; GSH-Px = glutathione peroxidase; $\mathrm{MDA}=$ malondialdehyde. 
Nawab A, Li G, Liu W, Lan R, Wu J, Zhao Y, Kang K, Kieser B, Sun C, Tang S, Xiao M, An L
Effect of Dietary Curcumin on the Antioxidant Status of Laying Hens under High-Temperature Conditions diets compared with the $\mathrm{HC}$ group fed only the basal diet, but no significant ( $p>0.05)$ differences were determined in the 6th week. CAT activity was also significantly $(p<0.05)$ increased in the lungs of hens submitted to heat stress and fed curcumin in the $3^{\text {rd }}$ week (treatments $\mathrm{H} 2, \mathrm{H} 4$ and $\mathrm{H} 5$ ), $6^{\text {th }}$ week (treatments $\mathrm{H} 2, \mathrm{H} 4$ and $\mathrm{H} 5$ ), and $9^{\text {th }}$ week (treatments $\mathrm{H} 2, \mathrm{H} 3$ and $\mathrm{H} 4$ ) of the experiment compared with the $\mathrm{HC}$ group fed only the basal diet. LungT-AOC activity of heatstressed hens fed diets supplemented with curcumin was significantly $(p<0.05)$ increased in the $3^{\text {rd }}$ week (treatments $\mathrm{H} 2$ and $\mathrm{H} 3$ ) and $9^{\text {th }}$ week (treatments $\mathrm{H} 3$, $\mathrm{H} 4$, and $\mathrm{H} 5$ ) of the experiment compared with the $\mathrm{HC}$ group fed only the basal diet, but was not significantly ( $p>0.05)$ different in the $6^{\text {th }}$ week. Furthermore, lung GSH-Px activity was also significantly $(p<0.05)$ increased in heat-stressed hens fed curcumin in the $3^{\text {rd }}$ week (treatments $\mathrm{H} 3$ and $\mathrm{H} 5$ ), $6^{\text {th }}$ week (treatment $\mathrm{H} 1$ ), and $9^{\text {th }}$ week (treatment $\mathrm{H} 3$ and $\mathrm{H} 4$ ) of the experiment compared with the $\mathrm{HC}$ group given only the basal diet.

The concentration of MDA in the liver, heart, and lungs was decreased in all heat-stressed groups fed graded curcumin levels $(\mathrm{H} 1, \mathrm{H} 2, \mathrm{H} 3, \mathrm{H} 4$ and $\mathrm{H} 5)$ compared with those submitted to heat stress or maintained at comfort temperature and fed only the basal diet (but not significantly), suggesting that dietary curcumin is capable of alleviating the deleterious effects of heat-stress, acting as an antioxidant (Wang et al., 2015). The significantly higher concentrations of MDA in the heat-stress control $(\mathrm{HC})$ hens observed in our study was in accordance with reports from studies with heat-stressed broiler chickens (Zhang et al., 2009; Ledoux, 2009; Habibi et al., 2014; Wang et al.,2015) and laying hens (Akbarian et al., 2011). Interestingly, the significantly higher activities of CAT, SOD, T-AOC, and GSH-Px obtained in the heatstressed hens fed diets supplemented with curcumin (200 and $250 \mathrm{mg} / \mathrm{kg}$ ) suggest that curcumin may provide a protective mechanism against oxidative stress and lipid peroxidation (Wang et al., 2015). This indicates the potential of dietary curcumin to initiate the biosynthesis of antioxidant enzymes, as well as to reduce heat-stress induced oxidative damage (Yarru et al., 2009). The mechanism that describes how dietary curcumin can reduce the negative effects of heat stress may explain that stressful environmental conditions stimulate the secretion of corticosteroids, which can be counteracted by dietary curcumin supplementation.

Taken together, the results of our study suggested that laying hens fed dietary curcumin at 200 and 250 $\mathrm{mg} / \mathrm{kg}$ had better heat tolerance compared with the control groups, which is reflected by higher activities of CAT, SOD, T-AOC, and GSH-Px, as well as lower MDA concentrations in the serum and tissue samples compared with the heat stress control group, which may help to protect the cells and tissues from lipid peroxidation. The results of present study also indicated that curcumin improves the antioxidant metabolites of birds, and can be a suitable feed additive as an alternative to synthetic antioxidants in the poultry diets which may enhance the bird's immunity against stressful environmental conditions.

\section{CONFLICT OF INTEREST}

We all authors agree that there is no conflict of interest with any organization regarding the material discussed in the manuscript.

\section{ACKNOWLEDGEMENTS}

Special thanks to Revista Brasileira de Ciência Avícola for giving an opportunity to share knowledge on worldwide heat stress issues and strategies to overcome this problem. The author wishes to thank beloved parents (Rana Nawab Ahmad and Mrs. R. Sultana), grandparents (Saith Bachal Din), uncle (Rana Maqbool Ahmad), brother (Rana Kashif Nawab and Dr. Rana Yasir Nawab) and dearest all teachers for continued support and excellent mentorship. This work was supported by Science and Technology Planning Project of Guangdong Province, China (2010 B090400376).

\section{ETHICS APPROVAL AND CONSENT TO PARTICIPATE}

According to rules and regulation of Guangdong Ocean University Animal Care and use Committee (Guangdong Province, China)

\section{REFERENCES}

Abdollah A, Golian A, Ahmadi AS. Effects of ginger root (Zingiber officinale ) on egg yolk cholesterol, antioxidant status and performance of laying hens. Journal of Applied Animal Research 2011;39(1):19-21.

Amalraj A, Pius A, Gopi S, Gopi S. Biological activities of curcuminoids, other biomolecules from turmeric and their derivatives - a review. Journal of Traditional and Complementary Medicine 2017;7(2):205-233.

Arab HA, Jamshidi R, Rassouli A, Shams G, Hassanzadeh H. Generation of hydroxyl radicals during ascites experimentally induced in broilers. British Poultry Science 2006;47(2):216-222.

Arslan M, Haq A, Ashraf M, lqbal J. Effect of turmeric (Curcuma Longa) supplementation on growth performance, immune response, carcass characteristics and cholesterol profile in broilers. Veterinaria 2017;66(1):1-5. 
Nawab A, Li G, Liu W, Lan R, Wu J, Zhao Y, Kang K, Kieser B, Sun C, Tang S, Xiao M, An L

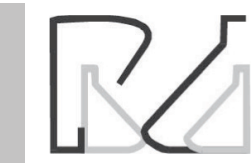

Effect of Dietary Curcumin on the Antioxidant Status of Laying Hens under High-Temperature Conditions
Chattopadhyay I, Biswas K, Bandyopadhyay U, Banerjee RK. Turmeric and curcumin: biological actions and medicinal applications. Current Science $2004 ; 87(1): 44-53$

Cleary K, McFeeters RF. Effects of oxygen and turmeric on the formation of oxidative aldehydes in fresh-pack dill pickles. Journal of Agricultural and Food Chemistry 2006;54(9):3421-3427.

Cousins M, Adelberg J, Chen F, Rieck J. Antioxidant capacity of fresh and dried rhizomes from four clones of turmeric (Curcuma longa L.) grown in bitro. Industrial Crops and Products 25(2):129-135.

Daneshyar, M. The Effect of dietary turmeric on antioxidant properties of thigh meat in broiler chickens after slaughter. Animal Science Journal 2012:83:599-604.

Dhanalakshmi S, Rathinasamy SD, Ramasundaram S, Sundaramahalingam $M$, Ramasundaram T. Protective effect of triphala on cold stressinduced behavioral and biochemical abnormalities in rats. Journal of the Pharmaceutical Society of Japan 2007;127(11):1863-1867.

Dinkova-Kostova AT, Talalay P. Direct and Indirect antioxidant properties of inducers of cytoprotective proteins. Molecular Nutrition \& Food Research 2008;52(Supl 1):s128-138

Guo JL, Zheng QH, Yin QQ, Cheng W, Jiang YB. Study on Mechanism of Ascites Syndrome of Broilers. American Journal of Animal and Veterinary Sciences 2007;2(3):62-65.

Habibi R, Sadeghi GH, Karimi A. Effect of different concentrations of ginger root powder and its essential oil on growth performance, serum metabolites and antioxidant status in broiler chicks under heat stress. British Poultry Science 2014;55(2):228-237.

Hassanzadeh M, Buyse J, Toloei T, Decuypere E. Ascites Syndrome in broiler chickens: a review on the aspect of endogenous and exogenous factors interactions. The Journal of Poultry Science 2014;51(3):229-241.

Ismail IB, Al-Busadah KA, El-Bahr SM. Oxidative Stress Biomarkers and Biochemical Profilr in Broilers Chickens Fed Zinc Bacitracin and Ascorbic Acid under Hot Climate. American Journal of Biochemistry and Molecular Biology 2013;3(2):202-214

Kokkinakis MDi, Brooks LJ. Tomato peroxidase purification, characterization, and catalytic properties. Plant Physiology 1979;63(1):93-99.

Ledoux DR. Effects of turmeric( Curcuma longa ) on the expression of hepatic genes associated with biotransformation, antioxidant, and immune systems in broiler chicks fed aflatoxin. Poultry Science 2009;88:2620-2627.

Lin H, Decuypere $E$, Buyse J. Acute heat stress induces oxidative stress in broiler chickens. Comparative Biochemistry and Physiology. Part A, Molecular \& Integrative Physiology 2006;(144):11-17.

Maheshwari R, Dubey RS. Nickel-induced oxidative stress and the role of antioxidant defence in rice seedlings. Plant Growth Regulator 2009;59:37-49.

Mittler R. Oxidative stress, antioxidants and stress tolerance. Trends in Plant Science 2002;7(9):405-410.

Motterlini R, Foresti R, Bassi R, Green CJ. Curcumin, an antioxidant and anti-inflammatory agent, induces heme oxygenase-1 and protects endothelial cells against oxidative stress. Free Radical Biology \& Medicine 2008;28(8):1303-1312.

Nawab A, Ibtisham F, Li G, Kieser B, Wu J, Liu W. Heat stress in poultry production: mitigation strategies to overcome the future challenges facing the global poultry industry. Journal of Thermal Biology 2018;78:131-139

Nawab A, Shuyan T, Wenchao L, Jiang W, Fahar I, Yi Z, Kai K, Chenyu S. Vitamin $\mathrm{E}$ and fertility in the poultry birds; deficiency of vitamin e and its hazardous effects. Approaches in Poultry Dairy \& Veterinary Sciences 2018;5(4):1-7
Nouzarian R, Tabeidian SA, Toghyani M, Ghalamkari G, Toghyani M. Effect of turmeric powder on performance, carcass traits, humoral immune responses, and serum metabolites in broiler chickens T. Journal of Animal and Feed Sciences 2011;20:389-400

NRC. Nutritional requirements of poultry. $9^{\text {th }}$ ed. Washington: The National Academic Press; 1994

Ohkawa H, Nobuko O, Kunio Y. Assay for lipid peroxides in animal tissues by thiobarbituric acid reaction. Analytical Biochemistry 1979;95(2):35158.

Pulido-Moran M, Moreno-Fernandez J, Ramirez-Tortosa C, Ramirez-Tortosa MC. Curcumin and health. Molecules 2016;21(3):1-22.

Rahmani M, Abolghasem G, Hassan K. Effects of Curcumin or nanocurcumin on blood biochemical parameters, intestinal morphology and microbial population of broiler chickens reared under normal and cold stress conditions. Journal of Applied Animal Research 2018;46(1):200-209.

Rahmani M, Abolghasem G, Hassan K, Mohammad RB. Effects of curcumin or nanocurcumin on blood biochemical parameters, intestinal morphology and microbial population of broiler chickens reared under normal and cold stress conditions. Journal of Applied Animal Research 2017;46(1):200-209.

Ramos L, Zúñiga Paredes JC, Moreno C. Effects of turmeric rhizome powder and curcumin on poultry production. A review. Journal of Animal and Feed Sciences 2017:26:293-302

Reis GS, Augusto VS, Silveira APC, Jordão AA, Baddini-Martinez J, Poli Neto $\mathrm{O}$, Rodrigues AJ, Evora RB. Oxidative-stress biomarkers in patients with pulmonary hypertension. Pulmonary Circulation 2013;3(4):856-861.

Singh RK, Diwakar R, Dipti Y, Bhargava A, Balzarini J, De Clercq E. Synthesis, antibacterial and antiviral properties of curcumin bioconjugates bearing dipeptide, fatty acids and folic acid. European Journal of Medicinal Chemistry 2010;45(3):1078-1086.

SPSS- Statistical Package for Social Sciences. Statistical software. SPSS; 1968

Srivastava S, Dubey RS. Manganese-Excess induces oxidative stress, lowers the pool of antioxidants and elevates activities of key antioxidative enzymes in rice seedlings." Plant Growth Regulation 2011;64:1-16.

Steel RGD, Torrie JH, Dickey DA. Principles and procedures of statistics. A biometrical approach. $3^{\text {rd }}$ ed. Cary: McGraw Hill Book; 1997,

Sun Y, Oberley LW, Li Y. A simple method for clinical assay of superoxide dismutase. Clinical Chemistry 1988;34(3):497-500

Toghyani M, Toghyani M, Abbasali G, Gholamreza G, Eghbalsaied S. Evaluation of cinnamon and garlic as antibiotic growth promoter substitutions on performance, immune responses, serum biochemical and haematological parameters in broiler chicks. Livestock Science 2011;138(1):167-173.

Wang D, Huifang H, Luli Z, Wei L, Hanlin Z, Guanyu H, et al. Effects of dietary supplementation with turmeric rhizome extract on growth performance, carcass characteristics, antioxidant capability, and meat quality of wenchang broiler chickens. Italian Journal of Animal Science2015; 14(3):344-349.

Wang D, Huifang H, Luli Z, Wei L, Hanlin Z, Guanyu $H$, et al. Effects of dietary supplementation with turmeric rhizome extract on growth performance, carcass characteristics, antioxidant capability, and meat quality of wenchang broiler chickens. Italian Journal of Animal Science 2015;14(3):1-7.

Wu Y, Yanmin $Z$, Changhui L, Hussain A, Hao $Z$, Jintian $H$, et al. Influence of butyrate loaded clinoptilolite dietary supplementation on growth performance, development of intestine and antioxidant capacity in broiler chickens. PLoS One 2016;11(4):1-15. 
Yarru LP, Settivari RS, Gowda NKS, Antoniou E, Ledoux DR, Rottinghaus GE. Effects of turmeric (Curcuma longa) on the expression of hepatic genes associated with biotransformation, antioxidant, and immune systems in broiler chicks fed aflatoxin. Poultry Science 2009;88(12):2620-1627.

Zeng T, Jin-jun L, De-qian W, Guo-qin L, Gen-lin W, Li-zhi L. Effects of heat stress on antioxidant defense system, inflammatory injury, and heat shock proteins of muscovy and pekin ducks :evidence for differential thermal sensitivities. Cell Stress and Chaperons 2014;13(3):895-901.
Zhang GF, Yang ZB, Wang Y, Yang WR, Jiang SZ, Gai GS. Effects of ginger root (Zingiber officinale) processed to different particle sizes on growth performance, antioxidant status, and serum metabolites of broiler chickens. Poultry Science 2009;88:2159-2266.

Zhang J, Xiang H, Hussain A, Hao Z, Lili Z, Wang T. Assessment of free radicals scavenging activity of seven natural pigments and protective effects in aaph-challenged chicken erythrocytes. Food Chemistry 2014; 145:57-65 
